\title{
The Effect of Niobium Addition on Mechanical Properties and Corrosion Resistance of a Medical Grade SS316L
}

\author{
I Nyoman Jujur ${ }^{1,2}$ \\ Sri Endah Susilowati ${ }^{3}$ \\ Seto Roseno ${ }^{1}$ \\ Agus Hadi Santosa Wargadipura ${ }^{1}$ \\ ${ }^{1}$ Center of Technology for Materials, Agency for the Assessment and Application of Technology \\ (BPPT), Indonesia \\ 2 Indonesian Institute of Technology, Indonesia \\ ${ }^{3}$ Faculty of Engineering, Department of Mechanical Engineering, 17 Agustus 1945 University, \\ Indonesia \\ *e-mail: nyoman.jujur@bppt.go.id
}

Submitted 31 January $2021 \quad$ Revised 08 September $2021 \quad$ Accepted 30 November 2021

\begin{abstract}
To improve mechanical properties, especially elongation, of as-cast medical grade 316 stainless steel, niobium $(\mathrm{Nb})$ was introduced into the alloys, followed by solution heat treatment. Alloying was performed using a $250 \mathrm{~kg}$ air induction melting furnace with duplex raw materials and ferronickel. Heat treatment using a solution at $1040{ }^{\circ} \mathrm{C}$, with a holding time of 45 minutes, and water quenching was used. The sample was tested using hardness and ultimate tensile machines. Corrosion tests with simulated body fluids were carried out using media with similar corrosion conditions to human blood. Microstructure observations were performed optically. The results show that the addition of $\mathrm{Nb}$ increases the hardness of medical grade $316 \mathrm{~L}$ stainless steel by $6 \%$ compared to the unalloyed steel, both before and after heat treatment. The addition of $\mathrm{Nb}$ increases the tensile strength by $8 \%$ compared to non-heat treated steel and increases the elongation before and after heat treatment by $8 \%$ and $5 \%$, respectively. However, the corrosion rate of the material with $\mathrm{Nb}$ is higher than without the addition of $\mathrm{Nb}$. $\mathrm{Nb}$ as a carbide former improves the mechanical properties of medical grade $316 \mathrm{~L}$ stainless steel but adversely affects its corrosion resistance.
\end{abstract}

Keywords: Nb addition, Medical grade SS 316L, Microstructure observation, Mechanical properties, Body fluid simulation

\section{INTRODUCTION}

The function of a biomedical implant is to replace biological parts/limbs in the body. Among various materials, metals and alloys like titanium and stainless steel (SS) are used as biomedical implants due to their superior mechanical properties, considerable biocompatibility, and ease of manufacturing
(Balla et al. 2013, Jaspreet Singh et al. 2018). A material frequently used for bone implants is austenitic $316 \mathrm{~L}$ stainless steel, which is economical, has excellent corrosion resistance, and has high strength (Suhendra 2005, Al-Sanabani et al. 2013, Dang et al. 2008, Daljinder Singh et al. 2017). Materials like nickel and chromium are not used because they could leach toxic metal ions 
(Singh et al. 2018). The manufacture of 316L stainless steel bone implants utilizing local ferronickel in an induction furnace with investment casting techniques has been developed for products requiring competitive prices with good quality. Fabricated bone implants using $316 \mathrm{~L}$ stainless steel apply investment casting techniques to reduce manufacturing costs without jeopardizing quality (Baharuddin et al. 2014). However, producing medical grade $316 \mathrm{~L}$ stainless steel materials having mechanical properties that comply with applicable medical material standards requires improvements in induction furnace melting and refining processes (Jujur et al. 2015).

Earlier research found triangular, hexagonal, and spherical forms of oxide inclusions in the stainless steel microstructure (Jujur et al. 2015). The presence of oxide phases influenced the tensile strength of $316 \mathrm{~L}$ stainless steel casting material specimens. However, problems associated with elongation values that are lower than required medical standards are still found in production technology development activities.

The advantages of niobium ( $\mathrm{Nb}$ ) as an alloying element have been known for many years. Niobium has a high affinity for carbon, an unfavorable size factor, and remains an independent phase providing potential nucleation sites. It also forms carbides at very high temperatures $\left(3000^{\circ} \mathrm{C}\right.$ ) (Hemmati et al. 2013, Huth et al. 2009, Theisen et al. 2007). Besides a higher wear resistance, the main advantage of large amounts of niobium carbides is that most of the chromium remains dissolved in the metal matrix, making the steel more resistant to corrosion (Huth et al. 2009, Anderson Edson da Silva et al. 2021). The role of chemical composition on hardness, wear, and corrosion resistance was evaluated by Theisen et al. (2007) for several wear-resistant iron-based alloys, including tool steels and casting alloys, with a hardfacing using several annealing temperatures. The niobium content of all investigated materials was around 5 to $6 \mathrm{wt}$.\%. The authors reported that alloys containing primarily niobium carbides had good resistance to abrasion wear. In addition, the higher affinity of niobium for carbon suppressed the formation of chromium carbides, leaving high amounts of chromium available for corrosion protection. Due to the technical importance of $\mathrm{Nb}$-stabilized austenitic steels, research interest in precipitation phenomena has been high over many years, and comprehensive reviews are available (Pickering and Keown 1981, Ayer et al. 1992, Solenthaler et al. 2015). Efforts were primarily aimed at characterizing precipitation reactions involving carbide, carbonitride, nitride, and intermetallic phase formation, and the evolution of secondary $\mathrm{NbX}$ populations regarding volume fraction, particle size, and stability against coarsening during long-term aging and creep (Kallqvist and Andren 1999, Ememan et al. 2004, Minami et al. 1985).

Niobium content leads to an increase in laves phase formation with the sigma phase, causing a significant increase in hardness and wear resistance with a decrease in the corrosion resistance of austenitic-ferritic stainless steels (Itman et al. 2014). The addition of niobium changes both the phase composition and the course of precipitation processes in cast steel (Chylinska et al. 2011). $\mathrm{Nb}$ precipitates control the austenite grain growth during subsequent heat treatment cycles. Furthermore, solute $\mathrm{Nb}$ combined with molybdenum, or accelerated cooling can produce bainite or acicular ferrite, enhancing strength and toughness simultaneously (Tither et al. 2001). 
180 The Effect of Nb Addition on Mechanical Properties and Corrosion Resistance of a Medical Grade SS316L

In this work, the effects of $\mathrm{Nb}$ on the microstructure, tensile strength, elongation, and corrosion resistance in medical grade 316 L stainless steel produced using Pomalaa, Indonesia-based ferronickel, were investigated.

\section{MATERIALS AND METHODS}

The chemical composition requirements for $316 \mathrm{~L}$ stainless steel bone implants are provided in the ASTM F 138 (Laing 1979) and ISO 5832-1 (ISO 5832-1) specifications. The chemical composition limits for bone implants in both the ASTM and ISO standards are nearly identical, with slight differences in the maximum silicon and molybdenum content, as seen in Table 1. The reduction in the maximum sulfur content from $0.03 \%$ (commercial quality alloy) to $0.01 \%$ has a favorable effect on the volume fraction of sulfide inclusions. The lower phosphorous content provides somewhat better ductility, especially for the majority of surgical implants that are moderately or highly cold work-treated.

The charging calculation was performed by computer-aided simulation before the melting processes began. Two types of scraps-2205 stainless steel scrap, ferrochrome, and the Pomalaa ferronickelwere used to produce the medical grade $316 \mathrm{~L}$ stainless steel alloys. The $316 \mathrm{~L}$ stainless steel material synthesis consisted of the following processes. First, the steel scraps were melted at about $1600{ }^{\circ} \mathrm{C}$ in the $250 \mathrm{~kg}$ induction furnace. After the steel was homogeneously dissolved, the ferronickel, ferrochrome, and ferro molybdenum were added until the alloy dissolved. The chemical composition of the melting stainless steel was measured using a spectrophotometer. The alloying process was targeted to meet the medical-grade stainless steel chemical composition specified in ASTM F 138 (Laing 1979) and ISO 5832-1 (ISO 58321), which are used for bone implant applications. Finally, the melting stainless steel alloy was poured into the specimen mold. Alloy compositions with unalloyed $\mathrm{Nb}$ and alloyed $\mathrm{Nb}$ are designated as castings $\mathrm{C} 1$ and $\mathrm{C}_{2}$, respectively. The two alloy compositions shown in Table 2 meet the elemental composition limits as defined in the ASTM F 138 and ISO 5832-1 standard.

Preparation of the tensile specimens was conducted according to the JIS Z 2241 and SNI 07-0408 standards for casting products. Specimens were annealed in the air furnace at $1040{ }^{\circ} \mathrm{C}$ for 45 minutes and subsequently quenched in water. The remaining molten liquid metal is used to cast implant products using investment casting technology.

The metal specimens for the microstructural examinations were metallographically prepared by a standard procedure using a diamond polishing paste, followed by etching with a Kalling's reagent to reveal grain boundaries. Mechanical tests were conducted using a Vickers microhardness tester (Struers Durascan 10, Struers, Germany) according to ASTM E92, and a universal testing machine $(250 \mathrm{kN}$ Shimadzu AGS-X, Shimadzu Corporation, Japan) using ASTM E8. Microstructure observation was performed using a laser scanning confocal microscope (Keyence VKX250, Keyence International, Belgium) and a scanning electron microscope (JEOL type JSM 6390 A) equipped with energy-dispersive $X-$ ray spectroscopy (EDS).

The electrochemical method examined the interactions at the $316 \mathrm{~L}$ stainless steel surface in a corrosive media. The specimen was wet abraded with 500, 800, and 1200 emery paper, degreased with detergent, and finally cleaned with an ultrasonic cleaner in an 
alcohol solution. Electrochemical experiments were conducted in $0.9 \%$ sodium chloride at $37^{\circ} \mathrm{C}$, using a $316 \mathrm{~L}$ stainless steel disk as a working electrode. The experiments were conducted by polarization resistance using a G 273 potentiostat/galvanostat (Figure 1). The sample's corrosion resistance measurement results are obtained from the corrosion current density values during the test.

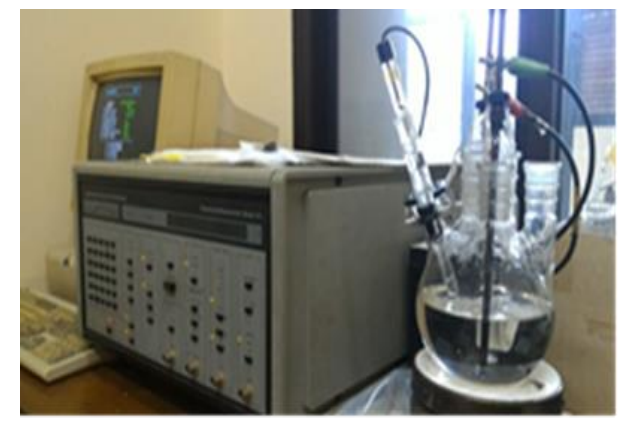

Fig. 1: Corrosion test equipment

\section{RESULTS AND DISCUSSION}

\section{Chemical Composition}

The medical-grade chemical composition for $316 \mathrm{~L}$ stainless steel bone implant materials is specified in the ASTM F 138 and ISO 5832-1 standard, as shown in Table 1. Table 2 shows the chemical composition for the castings with and without $\mathrm{Nb}$, showing that the main elements forming austenitic $316 \mathrm{~L}$ stainless steel meet the standard composition. The main elements for the smelting castings $\mathrm{C} 1$ and $\mathrm{C} 2$ have met the standard composition values, except for the C2 casting, which has $0.0395 \% \mathrm{Nb}$ content compared to the standard.

\section{Hardness Test}

Table 3 shows the results of the hardness tests before and after heat treatment. The addition of $\mathrm{Nb}$ (C2 Casting) increases the hardness by $6 \%$ both before and after heat treatment. The heat treatment process increases the hardness of the material by $5 \%$ with or without the addition of $\mathrm{Nb}$. This is shown by comparing the hardness value for casting C1 without heat treatment (130.6 HV) to the hardness value of casting $\mathrm{C} 1$ with heat treatment (137.4 HV). Hardness significantly increases from the casting material without $\mathrm{Nb}$ or heat treatment $(130.6 \mathrm{HV})$ to the casting with both $\mathrm{Nb}$ and heat treatment (146.0 HV), an $11.8 \%$ increase.

Table 1. Chemical requirements (wt.\%)

\begin{tabular}{ccc}
\hline & ASTM F 138 & ISO 5832-1 \\
\hline $\mathrm{C}$ & 0.03 max & 0.03 max \\
\hline $\mathrm{Si}$ & 0.75 max & 1.0 max \\
\hline $\mathrm{Mn}$ & $2.00 \mathrm{max}$ & $2.00 \mathrm{max}$ \\
\hline $\mathrm{P}$ & $0.025 \mathrm{max}$ & $0.025 \mathrm{max}$ \\
\hline $\mathrm{S}$ & $0.01 \mathrm{max}$ & $0.01 \mathrm{max}$ \\
\hline $\mathrm{Cr}$ & $17-19$ & $17-19$ \\
\hline $\mathrm{Ni}$ & $13-15$ & $13-15$ \\
\hline $\mathrm{Mo}$ & $2.25-3.0$ & $2.25-3.5$ \\
\hline $\mathrm{N}$ & 0.1 & 0.1 \\
\hline $\mathrm{Cu}$ & 0.5 & 0.5 \\
\hline $\mathrm{Fe}$ & Bal. & Bal. \\
\hline
\end{tabular}

Table 2. Chemical composition of the $316 \mathrm{~L}$ stainless steel (wt.\%) without $\mathrm{Nb}$ (casting $\mathrm{C} 1$ ) and with the addition of $\mathrm{Nb}$ (casting $\mathrm{C2}$ )

\begin{tabular}{ccc}
\hline & Casting C1 & Casting C2 \\
\hline $\mathrm{C}$ & 0.220 & 0.020 \\
\hline $\mathrm{Si}$ & 0.370 & 0.380 \\
$\mathrm{Mn}$ & 0.905 & 0.905 \\
\hline $\mathrm{P}$ & 0.0235 & 0.024 \\
\hline $\mathrm{S}$ & 0.0077 & 0.0064 \\
\hline $\mathrm{Cr}$ & 17.680 & 17.840 \\
\hline $\mathrm{Ni}$ & 14.510 & 13.995 \\
\hline $\mathrm{Mo}$ & 2.615 & 2.630 \\
\hline $\mathrm{Nb}$ & 0.000 & 0.0395 \\
\hline $\mathrm{Fe}$ & Balance & Balance \\
\hline
\end{tabular}

Filipovic et al. (2013) observed that niobium substantially modified the 
182 The Effect of Nb Addition on Mechanical Properties and Corrosion Resistance of a Medical Grade SS316L

microstructure by refining the dendrite size and causing a partial replacement of $\mathrm{M}_{7} \mathrm{C}_{3}$ chromium carbides by niobium monocarbides. Niobium monocarbides have a higher melting point and hardness than most other carbides. This improvement in the microstructure results in an increase in hardness, wear-resistance, and fracture toughness. The current research has also demonstrated that an increase in $316 \mathrm{~L}$ stainless steel hardness occurred after the addition of $\mathrm{Nb}$.

Table 3. Hardness properties

\begin{tabular}{cc}
\hline & $\begin{array}{c}\text { Vicker's Hardness } \\
\text { (HV) }\end{array}$ \\
\hline & NHT \\
\hline Casting C1 & 130.6 \\
\hline Casting C2 & 138.9 \\
\hline & $\mathrm{HT}$ \\
\hline Casting C1 & 137.4 \\
\hline Casting C2 & 146.0 \\
\hline
\end{tabular}

\section{Tensile Properties}

Table 4 shows the ultimate tensile strength (UTS), yield strength (YS), and elongation of the $\mathrm{C} 1$ and $\mathrm{C} 2$ casting samples. The addition of $\mathrm{Nb}$ (C2 casting) increases the tensile strength by $7.7 \%$ and the elongation by $8.7 \%$ for non-heat-treated $316 \mathrm{~L}$ stainless steel compared to the unalloyed steel ( $C 1$ casting). The final strength of the $\mathrm{C} 2$ casting was greater than the value from the ASTM $F$ 138 standard, with a minimum of $490 \mathrm{MPa}$.

In addition, the yield strength of the $\mathrm{C2}$ casting was greater than the ASTM $F 138$ standard, with a minimum value of $190 \mathrm{MPa}$. Elongation of the $\mathrm{C} 2$ casting meets the standard value (ASTM > 40), while the elongation of the $\mathrm{C} 1$ casting does not. However, after heat treatment, the effect of $\mathrm{Nb}$ addition on ultimate strength is not significant but increases the elongation value by $5.4 \%$. The heat treatment process can increase the mechanical strength both with or without $\mathrm{Nb}$ addition, so the strength values meet the standards.

Table 4. Tensile properties

\begin{tabular}{cccc} 
& $\begin{array}{c}\text { Ultimate } \\
\text { Tensile } \\
\text { Strength } \\
\text { (MPa) }\end{array}$ & $\begin{array}{c}\text { Yield } \\
\text { Strength } \\
\text { (MPa) }\end{array}$ & $\begin{array}{c}\text { Elongat } \\
\text { ion }\end{array}$ \\
\hline & & NHT & \\
\hline $\begin{array}{c}\text { Casting } \\
\text { C1 }\end{array}$ & 464.00 & 231.68 & 38.28 \\
\hline $\begin{array}{c}\text { Casting } \\
\text { C2 }\end{array}$ & 500.00 & 255.00 & 41.60 \\
\hline $\begin{array}{c}\text { Casting } \\
\text { C1 }\end{array}$ & 509.50 & 269.50 & 41.95 \\
\hline $\begin{array}{c}\text { Casting } \\
\text { C2 }\end{array}$ & 493.33 & 267.68 & 44.217 \\
\hline
\end{tabular}

Table 4 shows that the elongation of the $\mathrm{C} 2$ casting ( $\mathrm{Nb}$-alloyed) specimen is higher than for the unalloyed $\mathrm{C} 1$ casting. The beneficial impact of niobium can be due to three basic effects: grain size control, transformation control, and precipitation hardening. These three effects can be used either individually or in combination. Precipitation hardening essentially occurs at high solubility and temperatures, forming precipitates that block dislocation so that a reinforcing mechanism occurs. This phenomenon also occurs in Nb-alloyed 316L stainless steel (C2 casting). The Nb in $316 \mathrm{~L}$ stainless steel will dissolve in the austenite phase at $1040{ }^{\circ} \mathrm{C}$ and form precipitate $\mathrm{Nb}$ (CN) during cooling.

This $\mathrm{Nb}$ precipitate $(\mathrm{CN})$ is called carbonitride, a type of carbide that can block the movement of dislocations at the grain boundaries causing reinforcement in the 
steel. Niobium may form $\mathrm{Nb}$ precipitates (CN) because it has a high affinity for carbon (C) and nitrogen $(\mathrm{N})$. Precipitate monocarbides will inhibit grain growth by pinning grain boundaries. Generally, elongation tends to improve with additional $\mathrm{Nb}-\mathrm{V}$ content. These changes are considered to be the consequences of differences in precipitation distribution.

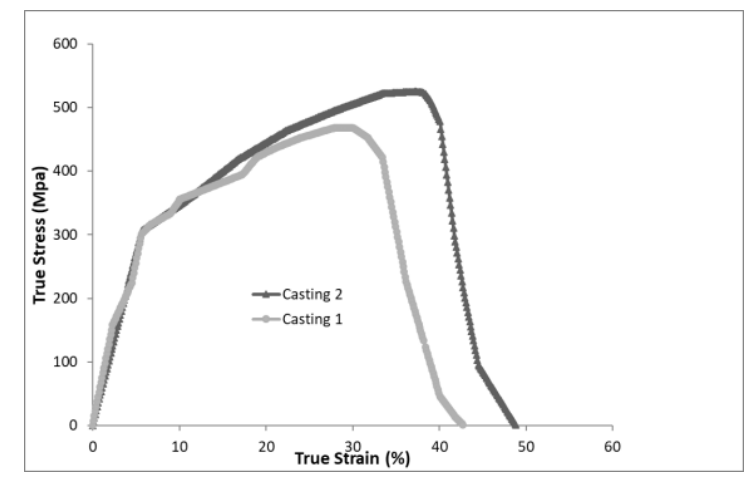

(a)

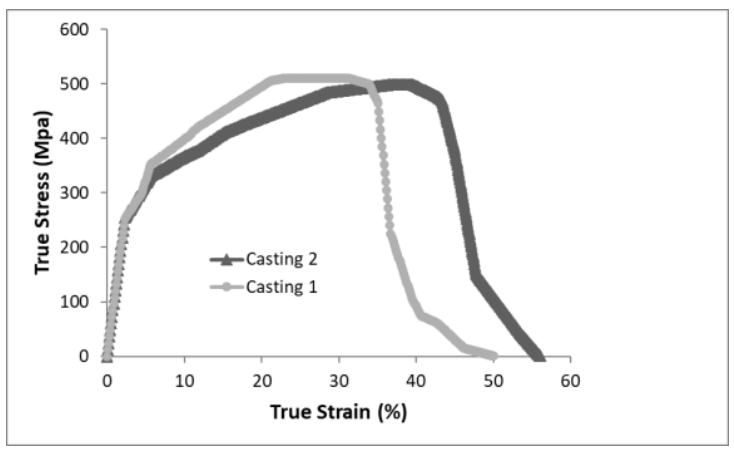

(b)

Fig. 2: Graph of stress-strain: (a) Non-heat treatment; and (b) Heat treatment

High strength and good toughness in micro-alloyed steels are achieved through a combination of micro-alloying and controlled rolling (Dutta and Sellars 1986). During sintering and subsequent slow cooling, $\mathrm{NbC}(\mathrm{N})$ or $\mathrm{VC}(\mathrm{N})$ precipitates form in austenite and ferrite during the austeniteferrite transformation or after transformation (Erden et al. 2016). This precipitate formation leads to an increase in strength compared to niobium and vanadium-free alloys. The hardness of powder metallurgy steels can increase with $\mathrm{VC}(\mathrm{N})$ and $\mathrm{NbC}(\mathrm{N})$ precipitates. Other studies (Mikrolegiranih 2011, Du et al. 2007, Karbulut et al. 2016) have indicated that carbides and nitrides formed in micro-alloyed steels improve their hardness and strength. These studies argued that solid solution hardening contributed less to strength than carbide and nitride precipitation.

The effect of $\mathrm{Nb}$ alloying on the elongation of 316L stainless steel can be seen in the graph of true stress and strain shown in Figure 2. From this graph, there is clearly an increase in elongation value for the $\mathrm{C} 2$ casting compared to the $\mathrm{C} 1$ casting, both before and after heat treatment.

\section{Corrosion Rate}

Corrosion current density ( $\left.\mathrm{I}_{\text {corr }}\right)$ values were acquired from polarization curves by extrapolating the cathodic branch of the curve to the corrosion potential. Corrosion current density ( $\mathrm{I}_{\text {corr }}$ ), corrosion potential (Ecorr), and corrosion rate for different casting and heat treatment processes are provided in Table 5. The corrosion rate was calculated from the corrosion current using Faraday's Law, either in terms of penetration rate or mass loss rate. When the corrosion reaction mechanisms are known, the corrosion currents can be calculated using Tafel slope analysis. Any factors that enhance the corrosion current value result in enhanced corrosion rates on pure kinetic grounds.

The corrosion rate of the C2 casting increases after heat treatment. However, as shown in Table 5, the corrosion rate decreases after heat treatment for the $\mathrm{C} 1$ casting. The difference in the corrosion rates of the $\mathrm{C} 1$ and C2 castings is allegedly affected by the influence of raw materials and heat treatment during the manufacturing process.

From Table 5, the corrosion potential observed for 316L Stainless steel in Ringer's 
184 The Effect of Nb Addition on Mechanical Properties and Corrosion Resistance of a Medical Grade SS316L

solution without heat treatment was -250.78 $\mathrm{mV}$ for the $\mathrm{C} 1$ casting and -234.96 for the $\mathrm{C} 2$ casting. The corrosion potentials with heat treatment were -134.46 for the $\mathrm{C} 1$ casting and -207.52 for the $\mathrm{C} 2$ casting. It was found that the corrosion potential $\left(E_{\text {corr }}\right)$ decreased with $\mathrm{Nb}$-alloying. On the contrary, corrosion current density (Icorr) increased with $\mathrm{Nb}$ alloying. After heat treatment, the corrosion current density was measured as $0.01 \mathrm{~mA}$ for unalloyed steel and $0.21 \mathrm{~mA}$ for $\mathrm{Nb}$-alloyed steel. Along with corrosion current density, the corrosion rate increases with $\mathrm{Nb}$-alloying. Corrosion rates were measured at 0.0056 MPY for the heat-treated C1 casting, increasing to $0.0857 \mathrm{MPY}$ for the heat-treated C2 casting.

Table 5. Corrosion rate

\begin{tabular}{lccc} 
& $\begin{array}{c}\mathbf{E}(\mathrm{I}=\mathbf{0}) \\
\mathbf{m V}\end{array}$ & $\begin{array}{c}\text { Icorr } \\
(\boldsymbol{\mu A} / \mathbf{C m} \\
\mathbf{2})\end{array}$ & $\begin{array}{c}\text { Corrosi } \\
\text { on rate } \\
(\mathbf{M P Y})\end{array}$ \\
\hline & \multicolumn{3}{c}{$\mathrm{NHT}$} \\
\hline Casting C1 & -250.78 & 0.0200 & 0.0079 \\
\hline Casting C2 & -234.96 & 0.1300 & 0.0560 \\
\hline & \multicolumn{3}{c}{$\mathrm{HT}$} \\
\hline Casting C1 & -134.46 & 0.0100 & 0.0056 \\
\hline Casting C2 & -207.52 & 0.2100 & 0.0857 \\
\hline
\end{tabular}

The corrosion resistance of a material is quantified by its rate of corrosion. The corrosion rate can be calculated by measuring the mass lost during the electrochemical reaction and is a function of a material's metallurgical factors, such as heating or the addition of alloys. From Table 5 , it can be seen that there is a decrease in corrosion resistance with the addition of $\mathrm{Nb}$ (C2 casting). The corrosion rate increases with the addition of $\mathrm{Nb}$ both before or after heat treatment. For the $\mathrm{C} 1$ casting after heat treatment, the corrosion rate was 0.0056 MPY, and for the C2 casting, the corrosion rate rose to $0.0857 \mathrm{MPY}$. While for the nonheat treated $\mathrm{C} 1$ casting sample, the corrosion rate is $0.0079 \mathrm{MPY}$, with the addition of $\mathrm{Nb}$, the corrosion rate rose to $0.056 \mathrm{MPY}$. In the microstructure observations with the optical microscope (Figure 3), it is clear that the oxide inclusion diameter increases for the $\mathrm{Nb}$ alloyed sample with heat treatment.

The addition of $\mathrm{Nb}$ increases the elongation of the specimen compared to the unalloyed sample. However, the corrosion rate of the steel with $\mathrm{Nb}$ addition is higher than without the addition of $\mathrm{Nb}$. $\mathrm{Nb}$ as a carbide former can increase the elongation values of medical grade $316 \mathrm{~L}$ stainless steel but with an adverse effect on corrosion resistance.

\section{Microstructure Test}

Observations of the casting microstructure through the SEM microscope are shown in Figure 3, where the difference between heat-treated $C 1$ and $C 2$ castings can be clearly seen. Black spots are spread evenly in the grains or their boundaries, and the number of black spots in the C2 casting appears to cover a greater area than for C1 casting. The sizes of the black spots are not too different between $\mathrm{C} 1$ casting and $\mathrm{C} 2$ casting.

Several types of inclusions were found from the SEM-EDX results. Inclusions with significant atomic \% of $\mathrm{O}, \mathrm{Si}$, and $\mathrm{Mn}$ are suspected to be combinations of $\mathrm{SiO}_{2}$ and MnO (Figure 4a). We also found other inclusions with $\mathrm{Ca}, \mathrm{K}$ and $\mathrm{Ti}$, thought to be $\mathrm{CaO}, \mathrm{K}_{2} \mathrm{O}$, and $\mathrm{TiO}_{2}$. The inclusion with a significant amount of carbon is carbide, as shown in Figure $4 \mathrm{~b}$.

The addition of $\mathrm{Nb}$ can increase the elongation of the specimen. However, the corrosion rate of the material with the 
addition of $\mathrm{Nb}$ is higher. $\mathrm{Nb}$ as a carbide former can increase the elongation value of medical grade $316 \mathrm{~L}$ stainless steel but with adverse effects on corrosion resistance.

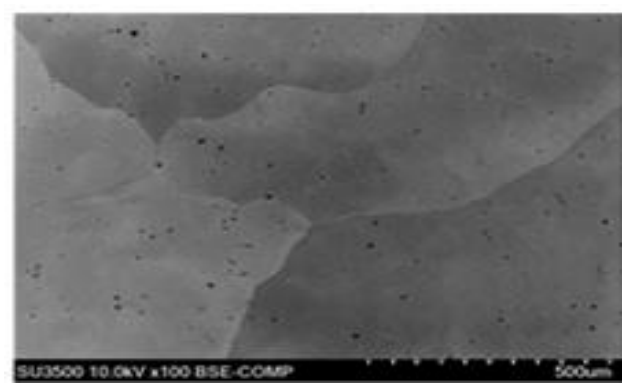

(a)

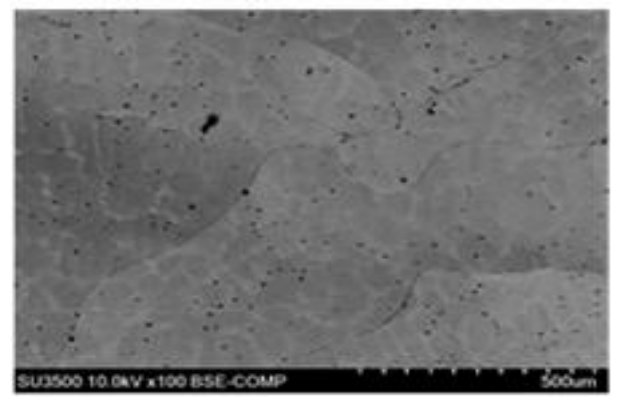

(b)

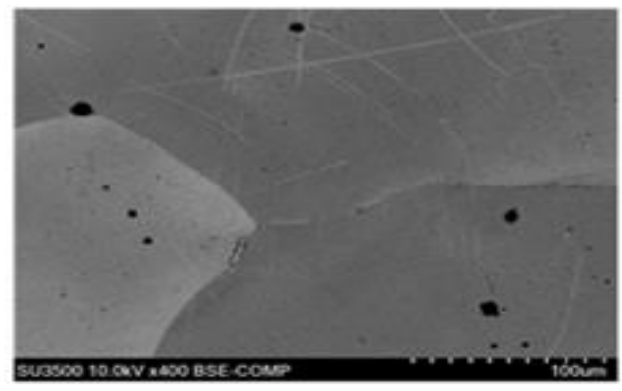

(c)

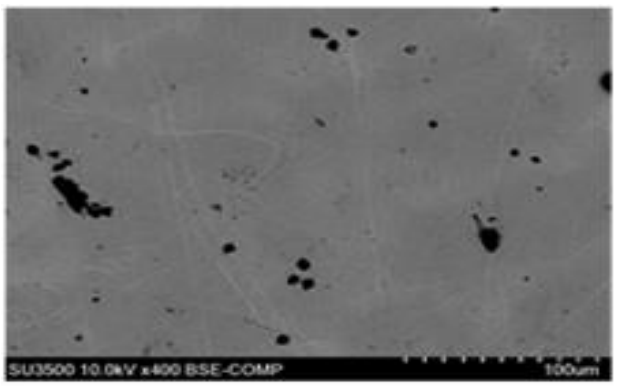

(d)

Fig. 3: SEM photographs of heat-treated casting specimens: (a) and (b) C1 casting; (c) and (d) C2 casting

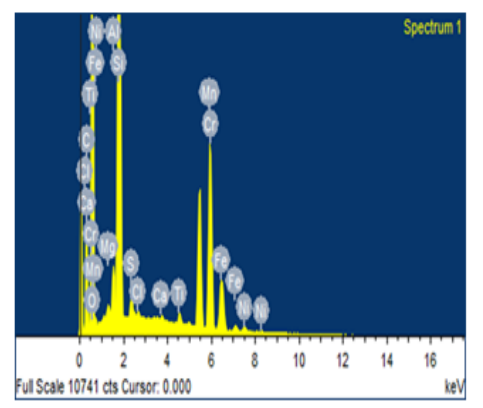

\begin{tabular}{|c|c|}
\hline Element & Atomic $\%$ \\
\hline $\mathrm{C}$ & 29.76 \\
\hline 0 & 48.05 \\
\hline $\mathrm{Mg}$ & 0.14 \\
\hline $\mathrm{Al}$ & 0.39 \\
\hline $\mathrm{Si}$ & 14.79 \\
\hline $\mathrm{S}$ & 0.17 \\
\hline $\mathrm{Cl}$ & 0.06 \\
\hline $\mathrm{Ca}$ & 0.05 \\
\hline $\mathrm{Ti}$ & 0.14 \\
\hline $\mathrm{Cr}$ & 2.26 \\
\hline $\mathrm{Mn}$ & 3.16 \\
\hline $\mathrm{Fe}$ & 0.89 \\
\hline
\end{tabular}

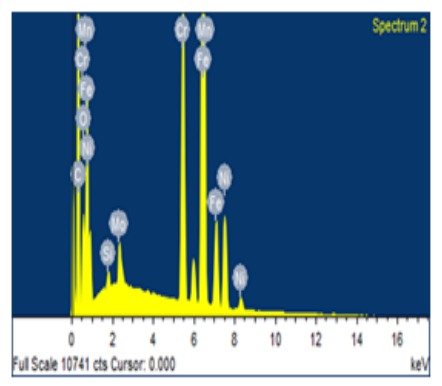

\begin{tabular}{|c|c|}
\hline Element & Atomic\% \\
\hline $\mathrm{C}$ & 73.00 \\
\hline 0 & 5.72 \\
\hline $\mathrm{Si}$ & 0.16 \\
\hline $\mathrm{Cr}$ & 4.18 \\
\hline $\mathrm{Mn}$ & 0.15 \\
\hline $\mathrm{Fe}$ & 13.68 \\
\hline $\mathrm{Ni}$ & 2.77 \\
\hline $\mathrm{Mo}$ & 0.34 \\
\hline
\end{tabular}

Fig. 4: SEM-EDX results for inclusions

\section{CONCLUSIONS}

This research investigated the effects of $\mathrm{Nb}$ addition on the microstructure, tensile strength, and corrosion resistance of medical grade $316 \mathrm{~L}$ stainless steel casting implants using local Pomalaa-based ferronickel. It was found that the addition of $\mathrm{Nb}$ increased the mechanical properties, especially the elongation by $8 \%$ for non-heat treated medical grade $316 \mathrm{~L}$ stainless steel and by $5 \%$ for heat-treated samples. However, the corrosion rate of the material with $\mathrm{Nb}$ addition was 15 times higher than without $\mathrm{Nb}$ addition. The solution heat treatment process increased the mechanical properties of the $316 \mathrm{~L}$ stainless steel either with or without $\mathrm{Nb}$ addition. $\mathrm{Nb}$ as a carbide former was shown to improve the mechanical properties of medical grade $316 \mathrm{~L}$ stainless steel but has adverse effects on its corrosion resistance. 
186 The Effect of Nb Addition on Mechanical Properties and Corrosion Resistance of a Medical Grade SS316L

\section{ACKNOWLEDGEMENT}

The authors would like to thank the Biomaterial Engineering Team of the Center of Technology for Materials and the Agency for the Assessment and Applications of Technology-BPPT Indonesia.

\section{REFERENCES}

1. Al-Sanabani, J. S., Madfa, A. A., \& AlSanabani, F. A. (2013). "Application of calcium phosphate materials in dentistry," Int. J. Biomater. 1-13

2. Ayer, R., Klein, C. F., \& Marzinsky, C. N. (1992). "Instabilities in stabilized austenitic stainless steels," Metall. Trans. A, 23(9), 2455-2467.

3. Baharuddin, M. Y., Salleh, S. H., Suhasril, A. A., Zulkifly, A. H., Lee, M. H., Omar, M. A., ... \& A Abdul Majid, N. (2014). "Fabrication of low-cost, cementless femoral stem $316 \mathrm{~L}$ stainless steel using investment casting technique," Artif. Organs, 38(7), 603-608.

4. Balla, V. K., Das, M., Bose, S., Ram, G. J., \& Manna, I. (2013). "Laser surface modification of $316 \mathrm{~L}$ stainless steel with bioactive hydroxyapatite," Mat. Sci. Eng. C, 33(8), 4594-4598.

5. Chylińska, R., Garbiak, P. C., \& Piekarski, B. (2011). "Analysis of precipitation processes in austenitic cast steel with niobium," Chem. Listy, 105(17), 806-807.

6. Dang, N. N., Kim, J. G., Huu, T. P., \& Yoon, D. H. (2008). "Corrosion properties of RNmagnetron sputtered tin coating deposited on 316L stainless steel," Abstract of the Korean Society of Surface Engineers Conference, 484-484.

7. Du, B., Zou, Z., Wang, X., \& Li, Q. (2007). "In situ synthesis of Tic-Tib 2 reinforced FeCrSiB composite coating by laser cladding," Surf. Rev. Lett., 14(02), 315319.

8. Dutta, B., \& Sellars, C. M. (1986). "Strengthening of austenite by niobium during hot rolling of micro-alloyed steel," Mater. Sci. Technol., 2(2), 146-153.

9. Erden, M. A., Gündüz, S., Karabulut, H., \& Türkmen, M. (2016). "Effect of vanadium addition on the microstructure and mechanical properties of low carbon micro-alloyed powder metallurgy steels," Mater. Test., 58(5), 433-437.

10. Erneman, J., Schwind, M., Liu, P., Nilsson, J. O., Andren, H. O., \& Ågren, J. (2004). "Precipitation reactions caused by nitrogen uptake during service at high temperatures of a niobium stabilised austenitic stainless steel," Acta Mater., 52(14), 4337-4350.

11. Filipovic, M., Kamberovic, Z., Korac, M., \& Gavrilovski, M. (2013). "Microstructure and mechanical properties of $\mathrm{Fe}-\mathrm{Cr}-\mathrm{C}-$ Nb white cast irons," Mater. Des., 47, 4148.

12. Hemmati, I., Huizenga, R. M., Ocelík, V., \& De Hosson, J. T. M. (2013). "Microstructural design of hard facing Ni-Cr-B-Si-C alloys," Acta Mater., 61(16), 6061-6070.

13. Huth, S., Krasokha, N., \& Theisen, W. (2009). "Development of wear and corrosion resistant cold-work tool steels produced by diffusion alloying," Wear, 267(1-4), 449-457.

14. ISO 5832-1, Implants for surgery-metallic materials, Part 1: Wrought stainless steel, International for Standardization, Geneva, Switzerland.

15. Itman Filho, A., Silva, R. V., Cardoso, W. D. S., \& Casteletti, L. C. (2014). "Effect of niobium in the phase transformation and corrosion resistance of one austenitic- 
ferritic stainless steel," Mater. Res., 17(4), 801-806.

16. Jujur, I. N., Sah, J., Bakri, A., \& Wargadipura, A. H. S. (2015). "Analysis of oxide inclusions on medical grade $316 \mathrm{~L}$ stainless steel using local raw," Int. J. Technol., 6(7), 1184-1190.

17. Karabulut, H., Türkmen, M., Erden, M. A., \& Gündüz, S. (2016). "Effect of different current values on microstructure and mechanical properties of microalloyed steels joined by the submerged arc welding method," Metals, 6(11), 281.

18. Källqvist, J., \& Andrén, H. O. (1999). "Microanalysis of a stabilised austenitic stainless steel after long term ageing," Mat. Sci. Eng. A, 270(1), 27-32.

19. Laing, P. G. (1979). Clinical Experience with Prosthetic Materials: Historical Perspectives, Current Problems, and Future Directions. Corrosion and Degradation of Implant Materials. ASTM STP 684, B.C. Syrett and A. Acharya, Eds., American Society for Testing and Materials, 202.

20. Mikrolegiranih, R. M. L. (2011). "Investigation into the mechanical properties of micro-alloyed as-cast steel," Mater. Tehnol., 45(2), 159-162.

21. Pickering, F. B., \& Keown, S. (1981). "Niobium in stainless steels. In Niobium," Proceedings of the International Symposium. Warrendale, PA: Met. Soc. AIME, 1113-1142.

22. Daljinder Singh, Rupinder Singh, K.S.Boparai, Ilenia Farina, Luciano Feo and Anita Kamra Verma (2017). "In-vitro studies of SS $316 \mathrm{~L}$ biomedical implants prepared by FDM, vapor smoothing and investment casting," Compos. B. Eng., 132, 107-114.

23. Solenthaler, C., Ramesh, M., Uggowitzer, P. J., \& Spolenak, R. (2015). "Precipitation strengthening of nb-stabilized TP347 austenitic steel by a dispersion of secondary $\mathrm{Nb}(\mathrm{C}, \mathrm{N})$ formed upon a short-term hardening heat treatment," Mat. Sci. Eng. A, 647, 294-302.

24. Suhendra, N., 2005. "Analysis of mechanical and thermal responses of total hip joint replacement acetabular components using fem models," Prosiding Semiloka Teknologi Simulasi dan Komputasi serta Aplikasi, 95-103.

25. Theisen, W., Siebert, S., \& Huth, S. (2007). "Wear-resistant steels and casting alloys containing niobium carbide," Steel Res. Int., 78(12), 921-928.

26. G. Tither (2001) Progress in Niobium Markets and Technology 1981-2001, Minerals, Metals, and Materials Society, Metals and Materials Society Minerals. Ed. Niobium Science \& Technology: Proceedings of the International Symposium Niobium 2001 (Orlando, Florida, USA) (Niobium 2001 Ltd, 2002). ISBN 9780971206809.

27. Y. Minami, H. Kimura, M. Tanimura. (1985). New Developments in Stainless Steel Technology, ASM, Metals Park, $\mathrm{OH}$.

28. Singh, J., Singh, R., Singh, H., \& Verma, A. K. (2018). "Investigations for mechanical properties and biocompatibility of SS316L implant prepared as rapid investment casting for batch production," Sādhanā, 43(5), 1-10.

29. Silva, A. E. D., Melo, I. N. R. D., Pinheiro, I. P., \& Silva, L. R. D. (2021). "Influence of Niobium Addition on Microstructure and Machinability of High Chromium Cast Iron," Mat. Res., 24 